\title{
Qualitative and Quantitative Phytochemical Composition of Sargassum Vulgare at Hurghada Red Sea Coast - Egypt
}

\author{
Seham E. Abu Ahmed ${ }^{* 1}$, Mohamed A. Deyab ${ }^{1}$, Fatma S. El-Ashry ${ }^{1}$ and Magda F. El-Adl ${ }^{1}$ \\ ${ }^{1}$ Department of Botany and Microbiology, Faculty of Science, Damietta University, New Damietta 34517, Egypt
}

Received: 13 December 2020 /Accepted: 12 January 2021

* Corresponding author's E-mail: Dr_Seham2016@yahoo.com

\begin{abstract}
Macroalgae produce a wide variety of chemically active secondary metabolites. Brown seaweed; Sargassum vulgare and its associated seaweeds were collected from Hurghada Red sea coast of Egypt. Optimal physicochemical properties; slightly alkaline; low turbidity, moderate temperature and available nutrient content of saline water produced massive growth of $S$. vulgare (53\% covering percentage) during autumn (2018). Heavy metals accumulation inside the investigated seaweed $S$. vulgare was within the usually range. The associated macroalgal species with $S$. vulgare are belonging to 9 genuses, 12 species. Chromatography, mass spectrophotometry (GC/MS) analysis revealed the presence of Twenty five bioactive compounds. The major phytochemical constituents in the chloroform extract of $S$. vulgare are n-Hexadecanoic acid 28.29\%, Heptacosane $8.04 \%$, trans13-Octadecenoic acid 5.50 \%, Oleic Acid 4.24 \%, Palmitoleic acid 3.56\% and Hexadecanoic acid, ethyl ester $3.30 \%$.
\end{abstract}

Keywords: Brown Seaweed, Sargassum vulgare, secondary metabolites, GC/MS, Phytochemical.

\section{Introduction}

Macroalgae is a collective term used for seaweeds and other benthic (attached to the bottom). Macro algae can be classified as red algae (Rhodophyta), brown algae (Phaeophyta) or green algae (Chlorophyta) depending on their nutrient and chemical composition (Manzelat et al. 2018). Seaweeds or macroalgae are some of the most important organisms maintaining the aquatic ecosystems stability (Satheesh $\boldsymbol{e t}$ al. 2017). However, macroalgae differ from other marine plants such as seagrasses and mangroves in that macroalgae lack roots, leafy shoots, flowers, and vascular tissues. Macroalgae take a wide range of forms, ranging from simple crusts, foliose (leafy), and filamentous (threadlike) forms with simple branching structures, to more complex forms with highly specialized structures for light capture, reproduction, support, flotation or attachment to the seafloor and size of macroalgae ranges from a few millimeters to plants up to 3-4 m high (Guillermo et al. 2008). Secondary metabolites from macroalgal species may be potentially bioactive compounds. These bioactive compounds can be incorporated into human food products for safety and preservation as they are edible, non-toxic and inexpensive (Hayes M et al. 2015). These compounds render the macroalgae as biological weapons which used for killing or incapacitating the targeted host (Noora et al. 2019). Marine macroalgae are rich in bioactive compounds 
that can be converted to a variety of secondary metabolites with a broad spectrum of biological activities (Yu P and Gu HF 2015). So macroalgae are considered as rich source for antibiotics production in the pharmacological industry (Aurora S et al. 2020). Various natural antimicrobial compounds have been recorded in marine environment more than those in the terrestrial one (Ireland et al. 1988). Seaweeds have been recognized as potential sources of the antibiotic substances (Chiheb et al. 2009).

"Sargassum" is a genus of brown (class Phaeophyceae) macroalgae (seaweed) in the order Fucales. Most species within the class Phaeophyceae was Sargassum which, are predominantly cold-water organisms that benefit from nutrients upwelling (Hogan $\boldsymbol{e t}$ al. 2011) grows subtidally and attaches to coral, rocks, or shells in moderately exposed or sheltered rocky or pebble areas. These tropical populations often undergo seasonal cycles of growth and decay in concern with seasonal changes in sea temperature (Fulton et al. 2014). Sargassum is considered as a source of bioactive compounds that give an alternative approach to the use of the synthetic antimicrobial agents. It's able to produce a great variety of secondary metabolites (Gonzalez $\boldsymbol{e t}$ al. 2001; Smit 2004) characterized by a broad spectrum of biological activities; antiviral, antibacterial (Chakraborthy et al. 2010a), antifungal and antitumor activities. The potent antimicrobial effect of seaweeds resides in the efficiency of the extraction method (Tuney $\boldsymbol{e t}$ al. 2006), the algal species (Valchos et al. 1997) and the solvents being used (Cox et al. 2010). Moreover, higher medicinal effect was obtained from dry seaweeds samples than from fresh samples as indicated by many studies which reported that extracts prepared from fresh seaweeds showed negligible antimicrobial activity compared to that obtained from dried seaweeds (Manivannan et al. 2011). Many investigations have demonstrated that a high dietary intake of natural phenols with the presence of several types of antioxidants such as flavonoids (Moraes-de-Souza et al. 2008) commonly found in plants and seaweeds reduce the risk of developing some chronic diseases, and various types of cancer so it offering a rich source of new drugs with potentially lower toxicity which strongly affect on longer life expectancy (Hodgson and Croft 2006; Halliwell 2007; Yan and Asmah 2010)

This study aimed to reveal: the vegetation
Sargassum vulgare and its associated macroalgae at Hurghada Red sea coast of Egypt during autumn 2018. Determine the Qualitative and Quantitative phytochemical composition of Sargassum vulgare which, extracted by using different solvents.

\section{Material and methods}

\section{(1) Study area}

Collection site was along Hurghada shores, Red sea coast of Egypt (Figure 1); it is one of the most important places of interest for algal growth in Egypt (intertidal zone).

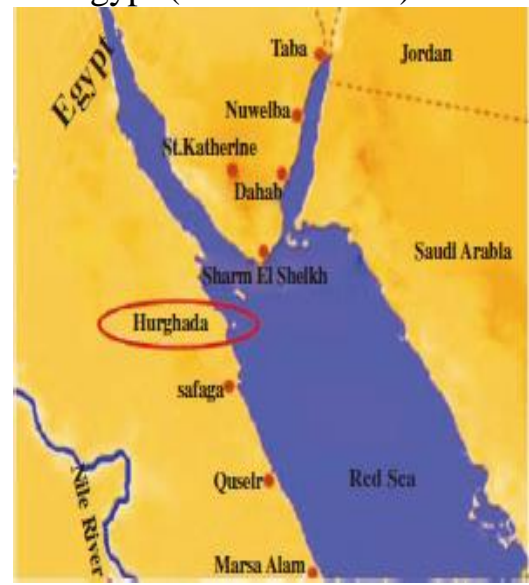

Figure. 1: Collection site of Sargassum Vulgare

\section{(2) Physico-chemical analysis of water}

Temperature determination by using a Celsius Thermometer.

Hydrogen ion concentration $(\mathrm{pH})$ by using a Horizon Ecology Co pH meter 5995.

Salinity (\%o), Conductivity (EC) and total dissolved salts (T.D.S) by using YSI Model 33 (yellow springs) S-C-T Meter \% MHOS.

Dissolved oxygen (DO) according to (EPA 1983) modified by (Wood 1975).

Biochemical oxygen demands (BOD) by (APHA 1992).

Total alkalinity and Phenolphthalein alkalinity by using the method of Kumar and Shailaja (1998).

Chlorides detection according to Ramteke and Moghe (1988).

Ammonia - nitrogen by using according to (Dawes et al. 1971).

Nitrite - nitrogen according to (Adams 1990).

Nitrate - nitrogen according to Strickland and Parsons (1965).

Total nitrogen by (Kryskalla 2003). 
Total phosphorus according to (EPA 1993).

Reactive (Ortho) Phosphate according to (APHA 1989).

Total hardness by (Diehl et al.1950).

Calcium Hardness according to Ramteke and Moghe (1988).

Magnesium Hardness according to Microkhjeldahl method of (Hawk et al. 1947). Determination of Heavy Metals according to Moore and Chapman (1986).

\section{(3) Collection and preparation of seaweeds}

The macro-algal species for the proposed study were collected from Hurghada, Egypt during autumn 2018. The Collected macro-algae was carefully examined and authenticated by prof. Dr. Mohammed Ali Deyab (prof. of phycology, Botany \& Microbiology Department, Faculty of Science, Damietta University). The selected sample of Sargassum vulgare (Fig. 2) and its associated seaweeds were triplicated collected by hand from one quadrat $(1 \times 1 \mathrm{~m})$ to determine the vegetation analysis of seaweed (covering $\%)$. The collected samples were washed with seawater at the sampling site to remove the adhered sediments and impurities and then packed in polyethylene bags and brought to the laboratory for further analyses.

\section{(4) Preparation of algal sample S. vulgare}

The selected predominant brown macro-algal species Sargassum vulgare was washed successively with tap water, distilled water to remove all the salt on the surface. The water was drained off and the seaweed was spread on blotting paper to remove excess water. The clean seaweed was shade dried at room temperature and ground to powder. The ground dried algal material stored in plastic bags in a dry place until use.

\section{(5) Phytochemical analysis of prepared Sargassum vulgare.}

Protein determination by Bradford (1976).

Total Soluble and Insoluble Sugars according to (Schortemeyer et al. 1997).

Lipids determination according to (Egan et al. 1981).

Potassium, Sodium and Calcium Ions determination by using method of (Hawk et al. 1947).

Heavy Metals determination according to
Moore and Chapman (1986).

\section{(6) Algal extract}

The Sargassum vulgare powder was successively extracted using solvents of increasing polarity according to (Arokiyaraj $\boldsymbol{e t}$ al. 2009) with some modifications. $15 \mathrm{~g}$ powder was initially soaked in $60 \mathrm{ml}$ of petroleum ether in air tight conical flask for two days. The flask was periodically subjected to shaking on an electronic shaker and then it was first filtered through double layered muslin cloth and then filtered through Whatman no. 1 filter paper and filtrate was collected into sterile air tight bottle. Likewise, the above methods were repeated using diethyl ether, ethyl acetate, acetone, chloroform, and ethyl alcohol 95\%, ethyl alcohol $70 \%$ and distilled water.

\section{(7) Qualitative analysis of natural products in algal extracts}

The phytochemical screening of different algal extracts was assessed by standard method as described by (Savithramma et. al. 2011). Phytochemical screening was carried out to identify the major natural chemical groups such as alkaloids, terpenoids, steroids, tannins, saponins, flavonoids, phenols, coumarins, quinones and glycosides. General reactions in these analyses revealed the presence or absence of these compounds in the algal extracts tested. Alkaloids identification, $2 \mathrm{~mL}$ of concentrated Hydrochloric acid $(\mathrm{HCl})$ was added to $2 \mathrm{~mL}$ algal extract. Then few drops Mayer's reagent was added. Presence of green color or white precipitate indicates the presence of alkaloids.

Terpenoids identification, $2 \mathrm{~mL}$ of chloroform along with concentrated Sulphuric acid was added to $0.5 \mathrm{ml}$ of the algal extract. Formation of reddish brown color at the interface indicates the presence of Terpenoids.

Steroids identification, $2 \mathrm{~mL}$ of chloroform and $1 \mathrm{~mL}$ of sulphuric acid $\left(\mathrm{H}_{2} \mathrm{SO}_{4}\right)$ were added to $0.5 \mathrm{~mL}$ of the algal extract. Formation of reddish brown ring at interface indicates the presence of steroids.

Tannins identification, one $\mathrm{mL}$ of ferric chloride $\left(5 \% \mathrm{FeCl}_{3}\right)$ was added to $1 \mathrm{~mL}$ of the algal extract. Formation of dark blue or greenish black color indicates the presence of tannins.

Saponins identification, $2 \mathrm{~mL}$ of distilled water was added to $2 \mathrm{~mL}$ algal extract and shaken in 
graduated cylinder for $15 \mathrm{~min}$ lengthwise. Formation of $1 \mathrm{~cm}$ layer of foam indicates the presence of saponins.

Flavonoids identification, $1 \mathrm{~mL}$ of $2 \mathrm{~N}$ sodium hydroxide $(\mathrm{NaOH})$ was added to $2 \mathrm{~mL}$ of algal extract. Formation of yellow color indicates the presence of flavonoids.

Phenols identification, $2 \mathrm{~mL}$ of distilled water followed by few drops of $10 \%$ ferric chloride was added to $1 \mathrm{~mL}$ of the algal extract. Formation of blue / green color indicates the presence of phenols.

Coumarins identification, $1 \mathrm{~mL}$ of $10 \% \mathrm{NaOH}$ was added to $1 \mathrm{~mL}$ of algal extract. Formation of yellow color indicates the presence of coumarins.

Quinones identification, $1 \mathrm{~mL}$ of concentrated sulphuric acid $\left(\mathrm{H}_{2} \mathrm{SO}_{4}\right)$ was added to $1 \mathrm{~mL}$ algal extract. Formation of red color indicates the presence of quinones.

Glycosides identification, $3 \mathrm{~mL}$ of chloroform and $10 \%$ ammonium solution was added to 2 $\mathrm{mL}$ of the algal extract. Formation of pink color indicates the presence of glycosides.

\section{(8) Quantitative analysis of phytochemical substances in algal extracts}

\section{Estimation of Total Phenolic Content}

The total phenolic content of dry extracts was performed with Folin-Ciocaltaeu assay described by Tambe and Bhambar (2014).

\section{Estimation of Total Tannin Content}

The tannins were determined by FolinCiocalteu method as described by Chandran and Indira (2016).

\section{Estimation of Total flavonoid Content}

Aluminum chloride colorimetric technique as described by (Chang et al. 2002).

\section{(9) Gas Chromatography Mass}

Spectrophotometry (GC/MS) Analysis

The GC/MS method is a direct and fast analytical approach for identification of algal extracts components. Extracts of Sargassum vulgare were performed using Trace GC-TSQ Quantum mass spectrometer (Thermo Scientific, Austin, TX, USA) with a direct capillary column TG-5MS (30 m x $0.25 \mathrm{~mm}$ x
$0.25 \mu \mathrm{m}$ film thickness). The column oven temperature was initially held at $50^{\circ} \mathrm{C}$ and then increased by $5^{\circ} \mathrm{C} / \mathrm{min}$ to $200{ }^{\circ} \mathrm{C}$ hold for $2 \mathrm{~min}$. increased to the final temperature of $290^{\circ} \mathrm{C}$ by $30^{\circ} \mathrm{C} / \mathrm{min}$ and hold for $2 \mathrm{~min}$. The injector and MS transfer line temperatures were kept at 270, $260^{\circ} \mathrm{C}$, respectively; Helium was used as a carrier gas at a constant flow rate of $1 \mathrm{ml} / \mathrm{min}$. The solvent delay was $3 \mathrm{~min}$, and diluted samples of $1 \mu \mathrm{l}$ were injected automatically using AS1300 coupled with GC in the split mode. EI mass spectra were collected at 70e.v. ionization voltages over the range of $\mathrm{m} / \mathrm{z} 50$ 500 in full scan mode. The ion source temperature was set at $200^{\circ} \mathrm{C}$. The components were identified by comparison of their retention times and mass spectra with those of WILEY 09 and NIST 11 mass spectral database.

\section{Result and discussion}

\section{Physicochemical analysis of the sea water}

At the study site (Hurgada, Red sea coast of Egypt) during autumn. Saline water was characterized with moderate alkaline reaction ( $\mathrm{pH}$ of 7.8), relatively high level of salinity $(417 . \%$ ), substantially high content of microelements Total $\mathrm{P}\left(2.82 \mathrm{mgL}^{-1}\right), \mathrm{PO}_{4}(0.26$ $\left.\mathrm{mgL}^{-1}\right)$, Total $\mathrm{N}\left(1.95 \mathrm{mgL}^{-1}\right)$ and Nitrate $(0.58$ $\mathrm{mgL}^{-1}$ ) (Table 1). Water temperature was $25^{\circ} \mathrm{C}$; dissolved oxygen concentrations were semistable with mean value of $11.8 \mathrm{mgL}^{-1}$. It's clear that the mean value of total calcium and magnesium hardness were $1510 \mathrm{mgL}^{-1}$ and $3160 \mathrm{mgL}^{-1}$ as $\mathrm{CaCO}_{3}$, respectively. Also Table (1) showed that the concentrations of major cations are changed with average values of 470 $\mathrm{mgL}^{-1}, 410 \mathrm{mgL}^{-1}$ and $12050 \mathrm{mgL}^{-1}$ for potassium, calcium and sodium, respectively. Biological oxygen demand (BOD), free $\mathrm{CO}_{2}$, $\mathrm{HCO}_{3}^{-}, \mathrm{CO}_{3}^{2-}$, total hardness, $\mathrm{Ca}$ hardness, $\mathrm{K}$, $\mathrm{Ca} . \mathrm{N}, \mathrm{Mn}, \mathrm{Zn}, \mathrm{Cu}, \mathrm{Ni}, \mathrm{Co}$ and $\mathrm{Cr}$ in sea water exhibited in low level.

Present results indicate that the optimal or semi-optimal physicochemical properties of saline water resulted in high growth of seaweeds with predominantly high growth of Sargassum vulgare (53\%) (Abdul Qudus et al. 2019). 
Table 1: physicochemical characteristics of sea water

\begin{tabular}{|c|c|}
\hline Characteristic & Autumn \\
\hline Temperature $\left(\mathrm{C}^{\circ}\right)$ & $25 \pm 1.5$ \\
\hline Salinity (\%o) & $4160 \pm 3.3$ \\
\hline PH & $7.8 \pm 0.1$ \\
\hline $\mathrm{EC}\left(\mathrm{mmhos} \mathrm{cm}^{-1}\right)$ & $57.1 \pm 0.1$ \\
\hline Alkalinity (meq $\mathbf{L}^{-1}$ ) & $2.9 \pm 0.1$ \\
\hline DO $\left(m g \mathbf{L}^{-1}\right)$ & $11.8 \pm 0.1$ \\
\hline BOD $\left(\mathrm{mg} \mathrm{L}^{-1}\right)$ & $1.8 \pm 0.01$ \\
\hline Free $\mathrm{CO}_{2}\left(\mathrm{mg} \mathrm{L}^{-1}\right)$ & $19.5 \pm 0.1$ \\
\hline $\mathrm{HCO}_{3-}\left(\mathrm{mg} \mathrm{L}^{-1}\right)$ & $0.75 \pm 0.02$ \\
\hline $\mathrm{CO}_{3}\left(\mathrm{mg} \mathrm{L}^{-1}\right)$ & $2.2 \pm 0.08$ \\
\hline T. Hardness $\left(\mathrm{mg} \mathrm{L}^{-1}\right)$ & $4670 \pm 0.02$ \\
\hline Ca Hardness $\left(\mathrm{mg} \mathrm{L}^{-1}\right)$ & $1510 \pm 0.03$ \\
\hline $\operatorname{Mg}$ Hardness $\left(\mathrm{mg} \mathrm{L}^{-1}\right)$ & $3160 \pm 0.02$ \\
\hline T. $K\left(\mathrm{mg} \mathrm{L}^{-1}\right)$ & $470 \pm 10$ \\
\hline T. Ca $\left(\mathrm{mg} \mathrm{L}^{-1}\right)$ & $410 \pm 7.0$ \\
\hline T. $\mathrm{Na}\left(\mathrm{mg} \mathrm{L}^{-1}\right)$ & $12050 \pm 0.02$ \\
\hline T. $P\left(\mathrm{mg} \mathrm{L}^{-1}\right)$ & $2.82 \pm 0.03$ \\
\hline $\mathrm{PO}_{4}\left(\mathrm{mg} \mathrm{L}^{-1}\right)$ & $0.26 \pm 0.01$ \\
\hline T. $N\left(\mathrm{mg} \mathrm{L}^{-1}\right)$ & $1.95 \pm 0.02$ \\
\hline Nitrate $\left(\mathrm{mg} \mathrm{L}^{-1}\right)$ & $0.58 \pm 0.03$ \\
\hline $\operatorname{Mg}\left(\mathrm{mg} \mathrm{L}^{-1}\right)$ & $2.69 \pm 0.11$ \\
\hline $\mathrm{Fe}\left(\mathrm{mg} \mathrm{L}^{-1}\right)$ & $1.75 \pm 0.04$ \\
\hline $\operatorname{Mn}\left(\mathrm{mg} \mathrm{L} \mathrm{L}^{-1}\right)$ & $1.93 \pm 0.04$ \\
\hline $\operatorname{Zn}\left(\mathrm{mg} \mathrm{L}^{-1}\right)$ & $0.55 \pm 0.01$ \\
\hline $\mathrm{Cu}\left(\mathrm{mg} \mathrm{L}^{-1}\right)$ & $1.68 \pm 0.02$ \\
\hline
\end{tabular}

Each value is the mean of three replicates \pm SE

\section{Seaweeds abundance and algal sampling}

The present result indicated that Surgassum vulgare (Figure 3) was predominant macroalgal species $53 \%$ followed by Sargassum muticum $10 \%$, S. crispum 5\%, Cystoseira trinodis 5\%, Laurencia papillosa 5\%, Dictyota dichotoma 5\%, C. myrica 2\%, Padina minor $2 \%$, Turbinaria ornata $2 \%$, Digenea simplex $2 \%$, Caulerpa racemosa $2 \%$, Halimeda tuna $2 \%$, Codium dichotomum $2 \%$, Cladophora koeiei $1 \%$, Hormophysa cuneiformis $1 \%$, Ulva lactuca 1\% as shown in (Figure 2). We select the consequently massive growth of Surgassum vulgare as principle seaweed for further studies to determine benefit natural product of macroalgae.

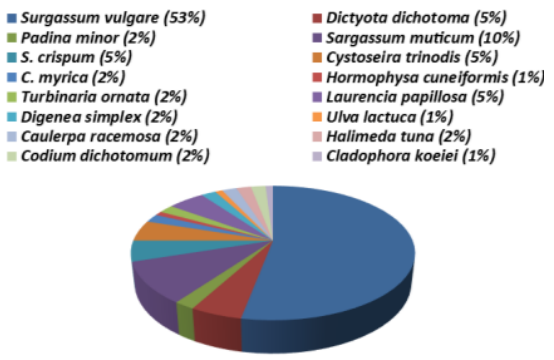

Figure 2: $S$. vulgare covering percentage and its associated macroalgal genera

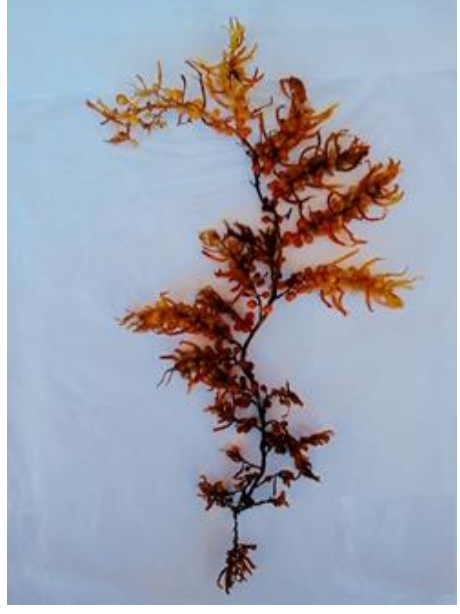

Figure 3: Sargassum vulgare

\section{Biochemical content of Sargassum Vulgare}

The present result of the biochemical content revealed that, the major contents were insoluble carbohydrate $(73.1 \mathrm{mg} / \mathrm{g}$ dry wt.) with relatively low content of soluble carbohydrate $(36.1 \mathrm{mg} / \mathrm{g}$ dry wt.). This may be due to the algae in the adult stage and accumulate insoluble carbohydrate as secondary metabolites for protective uses (Mariana et al. 2009). The minerals represent the second position in the biochemical contents of algae. This may be due to osmotic equilibrium of algae in hyper saline aquatic environment. Furthermore it has a considerable content of protein different groups of algae exhibit varying levels of tolerance to heavy metals. (Whitton 1970; Foster 1982b). It was observed greater $\mathrm{Fe}^{+}, \mathrm{Co}^{2+}, \mathrm{Cu} 2+$ and $\mathrm{Cd}^{2+}$ tolerance among the members $s$. vulgare $(4.1,1.4,0.2,0.1 \mathrm{mg} / \mathrm{mg}$ dry wt.) respectively (Table 2).

Table 2: phytochemical characteristics of Sargassum vulgare

\begin{tabular}{|c|c|}
\hline Characteristic & $\begin{array}{l}\text { mg/mg dry } \\
\text { wt. }\end{array}$ \\
\hline Protein $\left(\mathrm{mgL}^{-1}\right)$ & $15.4 \pm 0.1$ \\
\hline Soluble Carbohydrate $\left(\mathrm{mgL}^{-1}\right)$ & $36.1 \pm 0.4$ \\
\hline Carbohydrate & $73.1 \pm 0.3$ \\
\hline Lipids $\left(\mathrm{mgL}^{-1}\right)$ & $0.019 \pm 0$ \\
\hline Total $\mathrm{Na}^{+}\left(\mathrm{mgL}^{-1}\right)$ & $18.8 \pm 0.3$ \\
\hline Total $\mathrm{K}^{+}\left(\mathrm{mgL}^{-1}\right)$ & $48 \pm 2$ \\
\hline Total $\mathrm{Ca}^{++}\left(\mathrm{mgL}^{-1}\right)$ & $49 \pm 2$ \\
\hline $\operatorname{Cd}\left(\mathrm{mgL}^{-1}\right)$ & $0.059 \pm 0.0008$ \\
\hline Fe $\left(\mathrm{mgL}^{-1}\right)$ & $4.064 \pm 0.036$ \\
\hline $\mathrm{Cu}\left(\mathrm{mgL}^{-1}\right)$ & $0.20 \pm 0.0033$ \\
\hline $\operatorname{Co}\left(\mathrm{mgL}^{-1}\right)$ & $1.43 \pm 0.0069$ \\
\hline
\end{tabular}


Qualitative phytochemical composition of Sargassum vulgare

Preliminary phytochemical screening of ten different chemical compounds (alkaloids, terpenoids, steroids, tannins, saponins, flavonoids, phenols, coumarins, quinones and glycosides) were tested in ten different extracts. In the present study, the phytochemical screening was performed with petroleum ether, diethyl ether, ethyl acetat, aceton, chloroform, ethyl alcohol 95\%, ethyl alcohol $70 \%$ and distilled water extracts of Surgassum vulgare. Glycosides did not show any positive result for their presence in any of the ten extracts tested as shown in Table (3). Among the ten different extracts, chloroform extract showed the presence of maximum number; 9 of compounds. Next to that, acetone extracts showed five compounds. Diethyl ether extracts showed four compounds. Ethyl acetate and ethyl alcohol $70 \%$ extracts showed three compounds and petroleum ether and distilled water extracts showed only two. Soils under study have high contents of phaeophyta species and the predominance species were Sargassum. S. vulgare extracts have potential bioactive compounds with an effective antibacterial and antifungal activity. The present study indicated that the total bioactive products and their predominance and concentration area.

Table 3: Qualitative analyses of phytochemical composition of Surgassum vulgare extract

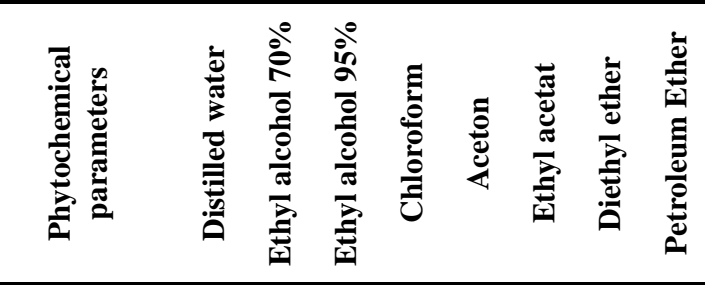

\begin{tabular}{lcccccccc}
\hline Alkaloids & - & - & - & + & - & - & - & - \\
Terpenoids & - & - & - & +++ & + & + & + & - \\
Steroids & - & - & - & +++ & + & + & + & + \\
Tannins & - & - & - & + & - & - & - & - \\
Saponins & - & - & - & ++ & - & + & - & + \\
Flavonoids & + & + & + & +++ & + & - & + & - \\
Phenols & - & - & - & ++ & - & - & - & - \\
Coumarins & + & + & + & ++ & + & - & + & - \\
Quinones & - & + & - & + & + & - & - & - \\
Glycosides & - & - & - & - & - & - & - & - \\
\hline
\end{tabular}

++: intensely present, +: Present, - : Absent

Flavonoids showed its presence in most tested extracts. Flavonoids have antimicrobial, antiviral, antioxidant and spasmolytic activity. Flavonoids have a considerable interest recently because of their potential beneficial effects on human health in fighting diseases. Phenols showed its presence in chloroform extract of Surgassum vulgare. In general, phenolic compounds possessed specific physical, chemical and biological activities that make them useful as drugs. Phenolics were also responsible for the antimicrobial, antiinflammatory, anti-viral, anticancer actions. Tannins were found only in chloroform extract. Coumarins were found in Diethyl ether, acetone, chloroform, ethyl alcohol 95\%, ethyl alcohol $70 \%$ and distilled water extracts and have been used as anti-coagulant to treat lymphedema. Quinones showed its presence in acetone, chloroform and ethyl alcohol 70\% extracts of Sargassum vulgare. Quinones confer cytotoxic activity via interference of DNA and RNA replication and mitochondrial oxidative pathways, as well as through the formation of peroxide, superoxide and hydroxyl radicals in the cell. Terpenoids were found in Diethyl ether, ethyl acetate, acetone and chloroform.

\section{Quantitative phytochemical composition of Sargassum vulgare}

Phenolics, flavonoids and tannins contents of Sargassum vulgare were varied according to solvents used in extraction processes. The highest total phenolics $(0.918 \pm 0 \mathrm{mg} \mathrm{GAE} / \mathrm{g}$ dry wt.) and tannins $(0.034 \pm 0.05 \mathrm{mg}$ RUE/g dry wt.) was recorded in chloroform extract, while the highest total flavonoids $(0.679 \pm 0.45$ mg CAE /g dry wt.) was recorded in Ethyl alcohol 95\% extract of Sargassum vulgare (Table 4). Simon et al. (2015) demonstrated that extraction solvents have an effect on phenolic and flavonoid contents

Table 4: Quantitative phytochemical composition of Sargassum vulgare extracts

\begin{tabular}{|c|c|c|c|}
\hline Solvents & $\begin{array}{c}\text { T. } \\
\text { phenolics } \\
\text { (mg } \\
\text { GAE/g dry } \\
\text { wt.) } \\
\end{array}$ & $\begin{array}{l}\text { T. flavonoids } \\
\text { (mg CAE /g } \\
\text { dry wt.) }\end{array}$ & $\begin{array}{c}\text { T. tannins } \\
\text { (mg } \\
\text { RUE/g } \\
\text { dry wt.) }\end{array}$ \\
\hline $\begin{array}{l}\text { Petroleum } \\
\text { ether }\end{array}$ & 0.551 & 0.156 & 0.001 \\
\hline Ether & 0.228 & 0.254 & 0.006 \\
\hline Aceton & 0.329 & 0.243 & 0.000 \\
\hline Chloroform & 0.918 & 0.172 & 0.034 \\
\hline $\begin{array}{l}\text { Ethyle } \\
\text { acetate }\end{array}$ & 0.266 & 0.265 & 0.011 \\
\hline $\begin{array}{l}\text { Ethyle } \\
\text { alcohol 95\% }\end{array}$ & 0.421 & 0.679 & 0.002 \\
\hline $\begin{array}{l}\text { Ethyle } \\
\text { alcohol 70\% }\end{array}$ & 0.232 & 0.378 & 0.005 \\
\hline Water & 0.199 & 0.018 & 0.001 \\
\hline
\end{tabular}


standard deviation $(n=3)$

GAE: Gallic acid equivalent, RUE: Rutin equivalent, CAE: Catechin equivalent.

\section{Gas Chromatography Mass Spectrophotometry} (GC/MS) Analysis

Metabolite profiling has been developed as modern technology platform in biological samples describe complex chemical matrices and identify the compounds. In particular, GC/MS is a fast and precise tool commonly used in diagnostics, functional genomics and screening (Rohloff, 2015). The present study contributes valuable information on bioactive compounds in Sargassum vulgare, as summarized in (Table 5). Sargassum contained numerous bioactive compounds belonging to various classes such as fatty acids, phenolics, alkaloids, flavonoids, steroids.

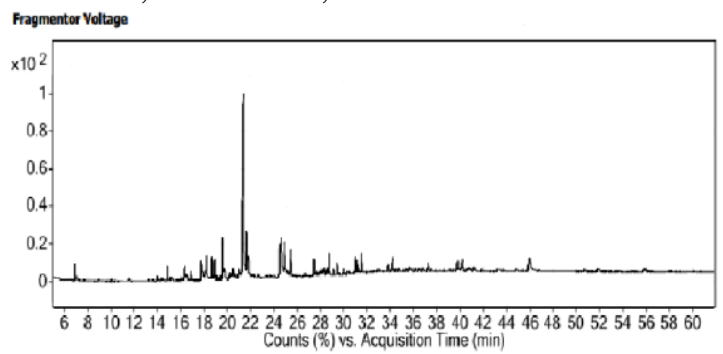

Figure 4: GC/MS chromatogram of Sargassum vulgare chloroformic extract

Chloroform extract of Sargassum vulgare was characterized by gas chromatography, mass spectrometer (GC/MS). The major constituents, retention time (RT), concentration (Area \%), chemical structure of bioactive components (CSBC), molecular formula (MF) and molecular weight (MW) are presented in (Table 5) and (Figure 4). Twenty bioactive compounds were identified in the chloroform extract of $S$. vulgare. The major phytochemical constituents are n-Hexadecanoic acid $28.23 \%$, Heptacosane $14.04 \%$, Oleic acid $9.10 \%$, Octadecane, 3-ethyl-5-(2-ethylbutyl) $4.8 \%$, Cholest-5-en-3-ol, 24-propylidene-, $\quad(3 \beta)$ 4.24\%, Ergosta-5,22-dien-3-ol, acetate, (3ß,22E) $4.21 \%$, and Palmitoleic acid $3.56 \%$. These bioactive compounds have many international knowledge uses in many fields as agriculture, pharmaceuticals, biotechnology, and industrial fields (Michalak et al. 2015, Guiheneuf et al. 2016).

Table 5: Chlorophormic extract components of Sargassum vulgare by GC/MS analysis

\begin{tabular}{|c|c|c|}
\hline Compound name & M Formula & $\underset{\%}{\text { Area }}$ \\
\hline Hexadecane & $\mathrm{C}_{16} \mathrm{H}_{34}$ & 1.4143 \\
\hline $\begin{array}{l}\text { 2-(4a,8-Dimethyl-6-oxo- } \\
\text { 1,2,3,4,4a,5,6,8a-octahydro- } \\
\text { naphthalen-2-yl)- } \\
\text { propionaldehyde }\end{array}$ & $\mathrm{C}_{15} \mathrm{H}_{22} \mathrm{O}_{2}$ & 1.4143 \\
\hline Tetradecanoic acid & $\mathrm{C}_{14} \mathrm{H}_{28} \mathrm{O}_{2}$ & 2.2628 \\
\hline Nonadecne & $\mathrm{C}_{19} \mathrm{H}_{40}$ & 3.0633 \\
\hline Butyl myristate & $\mathrm{C}_{18} \mathrm{H}_{36} \mathrm{O}_{2}$ & 2.2628 \\
\hline 17- Octadecynoic acid & $\mathrm{C}_{18} \mathrm{H}_{32} \mathrm{O}_{2}$ & 2.2628 \\
\hline $\begin{array}{l}\text { Cyclopenta [g]-2-benzopyran, } \\
\text { 1,3,4,6,7,8-hexahydro- } \\
\text { 4,6,6,7,8,8-hexamethyl- }\end{array}$ & $\mathrm{C}_{18} \mathrm{H}_{26} \mathrm{O}$ & 3.5696 \\
\hline $\begin{array}{l}\text { Hexadecanoic acid, methyl } \\
\text { ester }\end{array}$ & $\mathrm{C}_{17} \mathrm{H}_{34} \mathrm{O}_{2}$ & 0.85 \\
\hline n-Hexadecanoic acid & $\mathrm{C}_{16} \mathrm{H}_{32} \mathrm{O}_{2}$ & 28.23 \\
\hline Palmitoleic acid & $\mathrm{C}_{16} \mathrm{H}_{30} \mathrm{O}_{2}$ & 3.56 \\
\hline Hexadecanoic acid, ethyl ester & $\mathrm{C}_{18} \mathrm{H}_{36} \mathrm{O}_{2}$ & 3.30 \\
\hline Heptacosane & $\mathrm{C}_{27} \mathrm{H}_{56}$ & 14.04 \\
\hline $\begin{array}{l}\text { trans-13-Octadecenoic acid } \\
\text { (Oleic acid) }\end{array}$ & $\mathrm{C}_{18} \mathrm{H}_{34} \mathrm{O}_{2}$ & 9.10 \\
\hline 4,14-Retro-retinol & $\mathrm{C}_{20} \mathrm{H}_{30} \mathrm{O}$ & 1.698 \\
\hline $3-$ & $\mathrm{C}_{29} \mathrm{H}_{42} \mathrm{O}$ & 1.13 \\
\hline $\begin{array}{l}\text { Oxatricyclo[20.8.0.0 }(7,16)] \text { tria } \\
\text { conta-1 }(22), 7(16), 9,13,23,29- \\
\text { hexaene }\end{array}$ & & \\
\hline $\begin{array}{l}\text { 4-Hexyl-1-(7- } \\
\text { methoxycarbonylheptyl)bicycl } \\
\text { o[4.4.0]deca-2,5,7-triene }\end{array}$ & $\mathrm{C}_{25} \mathrm{H}_{40} \mathrm{O}_{2}$ & 1.41 \\
\hline $\begin{array}{l}3 \text { ',8,8'-Trimethoxy-3- } \\
\text { piperidyl-2,2' -binaphthalene- } \\
\text { 1,1',4,4'-tetrone }\end{array}$ & $\mathrm{C}_{28} \mathrm{H}_{25} \mathrm{NO}_{7}$ & 1.41 \\
\hline $\begin{array}{l}\text { Octadecane, 3-ethyl-5-(2- } \\
\text { ethylbutyl)- }\end{array}$ & $\mathrm{C}_{26} \mathrm{H}_{54}$ & 4.8 \\
\hline $\begin{array}{l}\text { Ergosta-5,22-dien-3-ol, } \\
\text { acetate, }(3 \beta, 22 \mathrm{E}) \text { - }\end{array}$ & $\mathrm{C}_{30} \mathrm{H}_{48} \mathrm{O}_{2}$ & 4.21 \\
\hline $\begin{array}{l}\text { Cholest-5-en-3-ol, } \\
\text { propylidene-, (3ß)- }\end{array}$ & $\mathrm{C}_{30} \mathrm{H}_{50} \mathrm{O}$ & 4.24 \\
\hline
\end{tabular}

\section{Conclusion}

The present results indicated that semi-optimal physicochemical properties of sea water resulted in high growth of several species of seaweeds with high predominance of Sargassum vulgare. This study concluded also that different extracts of Sargassum vulgare possess varied qualitative and quantitative content of chemical compounds including alkaloids, terpenoids, steroids, tannins, flavonoids, phenols, coumarins, quinones and Saponins but lacks glycosides compactable with biological properties of macro-algae and these according to type of extract solvents. There is no single solvent which may be considered standard because it is usually different for different plant matrices. The major phytochemical constituents in the chloroform extract of $S$. vulgare are n-Hexadecanoic acid $28.29 \%$, Heptacosane $8.04 \%$, trans-13- 
Octadecenoic acid 5.50\%, Oleic Acid 4.2428 $\%$, Palmitoleic acid $3.56 \%$ and Hexadecanoic acid, ethyl ester $3.30 \%$. This work also, indicated that the bioactive compounds of $S$. vulgare need further research to a scertain their biological properties.

\section{References}

Abdul Qudus A, Kishneth P, Farid G, Mohammed RI and Shariza A (2019). Effects of Seasonal Variability on the Physicochemical, Biochemical, and Nutritional Composition of Western Peninsular Malaysia Gracilaria manilaensis Molecules. Sep; 24(18): 3298.

Adams V (1990) "Water and wastewater examination manual". Lewis publishers, USA, pp. 247.

American Public Health Association (APHA) (1992). "Standard Methods for the Examination of water and Wastewater". Washington, 18th Ed.

Aurora S, Sofia AS, Carpena M, Garcia-Oliveira P, Gullón M, Fátima B, Prieto MA and SimalGandara J (2020). Macroalgae as a Source of Valuable Antimicrobial Compounds: Extraction and Applications. mprieto@uvigo.es (M.A.P.); jsimal@uvigo.es (J.S.G.).

Bradford MM (1976). A Rapid and Sensitive Method for The Quantification of Microgram Quantities of Protein Utilizing the Principle of Protein Dye Binding. Analytical Biochemistry, 72: 248-54.

Chakraborthy K, Lipton AP, Paulraj R and Vijayan KK (2010a). Antibacterial diterpernoids of Ulva fasciata Delile from South-western coast of Indian Peninsula Food. Chem., 119 (2010), pp. 1399-1408.

Chandran KCI and Indira G (2016). Quantitative estimation of total phenolic, flavonoids, tannin and chlorophyll content of leaves of Strobilanthes Kunthiana (Neelakurinji). Journal of Medicinal Plants Studies 2016; 4(4): 282-286.

Chang CC, Yang MH, Wen HM and Chern JC (2002). Estimation of Total Flavonoid Content in Propolis by Two Complementary Colorimetric Methods. Journal of Food and Drug Analysis. 10. 178-182. 10.38212/2224-6614.2748.

Chiheb I, Hassane R, Martinez L, José D, Francisco G, Antonio B, Hassan B and Mohamed K (2009). Screening of antibacterial activity in marine green and brown macroalgae from the coast of Morocco. Afr. J. Biotechnol., 8 (7) (2009), pp. 1258-1262.

Cox S, Abhu-Ghannam N and Gupta S (2010). An assessment of the antioxidant and antimicrobial activity of six species of edible Irish seaweeds.
Int. Food Res. J., 17, pp. 205-220.

DAWES EA and SENIOR PJ (1971). Polyphydroxybutyrate biosynthesis and the regulation of glucose metabolism in Azotobacter beijerinckii. Biochemical Journal 125, 55-66.

DIEHL H, GOETZ CA and HACH CC (1950). the versenate titration for total hardness. J. Amer. Water Works Assoc. 42:40.

Egan H, Kirk RS and Sawyer R (1981). Pearson's Chemical Analysis of Food. 8th Edn. Churchill Livingstone, Edinburgh, UK.

EPA (1983) "Methods foe Chemical Analysis of Water and Wastes". U.S. Environ. Protec. Agency, EPA-690/4-79-020, Cincinnati, OH.APHA.

EPA (1983) "Methods foe Chemical Analysis of Water and Wastes". U.S. Environ. Protec. Agency, EPA-690/4-79-020, Cincinnati, OH.APHA (1989).

Foster PL (1982a). Species associations and metal contents of algae from rivers polluted by heavy metals. Freshwater Bioi 12:17-39.

Fulton CJ, Depczynski M, Holmes TH, Noble MM, Radford B, Wernberg T and Wilson SK (2014). Sea temperature shapes seasonal fluctuations in seaweed biomass within the Ningaloo coral reef ecosystem. Limnology and Oceanography 59:156-166.

Gonzalez AD, Basilio PGA, Cabello A, Gorrochategul J, Suay I, Vicente F, Portillo E, Rio JDM, Garcia RG and Pelaez F (2001). Screening of antimicrobial activities in red, green and brown macroalgae from Gran canaria (Canary Islands, Spain). Int. Microbiol., 4 (2001), pp. 35-40.

Guiheneuf F, Khan A and Tran LS (2016). Genetic engineering: a promising tool to engender physiological, biochemical, and molecular stress resilience in green microalgae. Front. Plant Sci. 31:400. 10.3389/fpls.2016.00400.

Guillermo DP and Laurence JM (2008). State of the Reef Report Environmental Status of the Great Barrier Reef: Macroalgae (Seaweeds). (C) Commonwealth of Australia, ISBN 187694534 6.

Halliwell B (2007). Oxidative stress and cancer: have we moved forward? Biochem. J., 401 (2007), pp. 1-11.

Hawk FP, Oser L and Summerson SP (1947). A Convienent Titrimetric Ultramicromethod for the Estimation of Urea and Kjeldahl. N. J. Biol. Chem., 156: 281.

Hayes M (2015). Seaweeds: A nutraceutical and health food. In Seaweed Sustainability. 1st ed.; Tiwari, B.K., Troy, D.J., Eds.; Academic Press: London, UK,; pp. 365-387.

Hodgson JM and Croft KD (2006). Dietary 
flavonoids: effects on endothelial function and blood pressure. J. Sci. Food Agric., 86 (2006), pp. 2492-2498.

Hogan, Michael C, Monosson E and Cleveland CJ (2011). Brown algae Encyclopedia of Earth. Washington DC: National Council for Science and the Environment.

Ireland C, Roll D, Molinsk T, Mckee T, Zarbriske Tand Swersey J (1988). Uniqueness of the marine environment: categories of marine natural product from invertebrates D.G. Fautin (Ed.), Biomedical Importance of Marine Organisms, California Academy of Science. San Francisco, (1988), pp. 41-58.

Manivannan K, Karthikaidevi G, Anantharaman P and Balasubramanian T (2011). Antimicrobial potential of selected brown seaweeds from Vedalai coastal waters, Gulf of Mannar Asian. Pac. Trop. Biomed., 1, pp. 114-120.

Manzelat FS, Mohammed MA, Ahmed HB, Ali HN, Shuqaiq AH, Qahma A and Birk A (2018). Macro algae of the Red Sea from Jizan, Saudi Arabia. Phykos, 48: 88-108.

Mariana R, Carolina P, Griselda P, Roque I, Juan AG, Mirna H and Fernando EP (2009). Soluble sugars-Metabolism, sensing and abiotic stress: A complex network in the life of plants, Plant Signal Behav. May; 4(5): 388-393. doi: 10.4161/psb.4.5.8294

Michalak I and Chojnacka K (2015). Algae as production systems of bioactive compounds. Eng. Life Sci. 15 160-176. 10.1002/elsc.201400191

Moore P and Chapman S (1986). "Methods in Plant Ecology". Second Edition, Blackwell Scientific Publication, Osney Mead, Oxford, OX2 OEL

Moore P and Chapman S (1986). "Methods in Plant Ecology". Second Edition, Blackwell Scientific Publication, Osney Mead, Oxford, OX2 OEL.

Moraes-de-Souza RA, Oldoni TLC, Regitanode MAB and Alencar SM (2008). Antioxidant activity and phenolic composition of herbal infusions consumed in Brazil Cienc Technol. Aliment., 6 (2008), pp. 41-47.

Noora B, Saeid T, Hadi B and Fabio V (2019). Metabolites from Marine Microorganisms, Micro, and Macroalgae: Immense Scope for Pharmacology. Mar. Drugs , 17(8), 464.

Patton CJ and Kryskalla JR (2003) Methods of Analysis by the US Geological Survey National Water Quality Laboratory: Evaluation of Alkaline Persulfate Digestion as an Alternative to Kjeldahl Digestion for the Determination of Total and Dissolved Nitrogen and Phosphorus in Water. US Geological Survey, Water Resources Investigations Report 03-4174.

Ramteke DS and Moghe CA (1988). Manual on water and wastewater analysis. National Environmental Engineering Research Institute (NEERI), Nagpur.

Ramteke DS and Moghe CA, (1988) Manual on water and wastewater analysis. National Environmental Engineering Research Institute (NEERI), Nagpur.

Rohloff J (2015). Analysis of Phenolic and Cyclic Compounds in Plants Using Derivatization Techniques in Combination with GC-MS-Based Metabolite Profiling. Molecules. 20. 3431-3462. 10.3390/molecules20023431.

Satheesh S, Siddik A, Baakdah M and Al-Sofyani A (2017). An Introduction to the Ecological Significance of Seaweeds on Coastal Ecosystems, Biotechnological Applications of Seaweeds. ISBN 978-1-53610-968-9.

Savithramma N, Rao ML, Rukmini K and Devi PS (2011). Antimicrobial activity of silver nanoparticles synthesized by using medicinal plants. International Journal of Chem Tech Research, Vol 3(3), pp. 1394-1402.

Schortemeyer M, Stamp P and Feil B (1997). Ammonium Tolerance and Carbohydrate Status in Maize Cultivars. Annual of Botany, 79: 25-30.

Selvaraj A, Kantharaj P, Agastian P and Kumar R (2009). Phytochemical analysis and antibacterial activity of Vitex agnus-castus. International Journal of Green Pharmacy. 3. 10.4103/09738258.54912.

Simon BLA, Lidianys M, Lara ECL and David DH (2015). Solvent effects on phytochemical constituent profiles and antioxidant activities, using four different extraction formulations for analysis of Bucida buceras L. and Phoradendron ca. Res Notes, 8:396. DOI 10.1186/s13104-0151388-1.

Smit AJ (2004). Medicinal and pharmaceutical uses of seaweed natural products. A review J. Appl. Phycol., 16 (2004), pp. 245-262.

Strikland JD and Parsons HTR (1965). A practical handbook of seawater analysis. Bull. Fish. Res. Bd. Can. 167. Surveillance System Stations. U. S. Environmental Protection Agency National Environmental Research Center Analytical Quality Control Laboratory Cincinnati, Ohio.

Sunil kumar M, and Shailaja R (1998). Water studies: Methods for monitoring water quality. Center for Environmental Education, Bangalore.

Tambe BVD and Tambe RS (2014). Bhambar Estimation of total phenol, tannin, alkaloid and flavonoid in Hibiscus tiliaceus Linn. wood extracts. Res Rev J Pharmacog Phytochem, 2 (4), pp. 41-47.

Tuney I, Cadirci BH, Unal D and Sukatar A (2006). Antimicrobial activities of the extracts of marine 
algae from the coast of Urla (Izmir, Turkey). Turk. J. Biol., 30 (2006), pp. 171-175.

Valchos V, Critchley AT and Von Holy A (1997). Antimicrobial activity of extracts from selected Southern African marine macroalgae. South Afr. J. Sci., 93 , pp. 328-332.

Whitton BA (1970). Toxicity of heavy metals to Chlorophyta from running waters. Arch Mikrobiol 72:353-360.

Wood RB (1975). Hydrobiological methods. Univ.
Park Press, p. 3233.

Yan S and Asmah R (2010). Comparison of total phenolic contents and antioxidant activities of turmeric leaf, pandan leaf and torch ginger flower. Int. Food Res. J., 17, pp. 417-23.

Yu P and Gu HF (2015). Bioactive substances from marine fishes, shrimps, and algae and their functions: present and future. Crit Rev Food Sci Nutr 55:1112-1134.
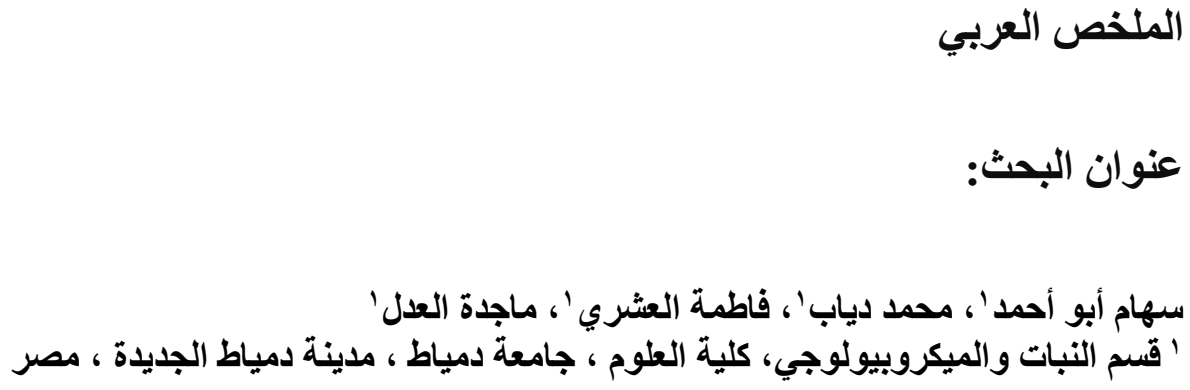

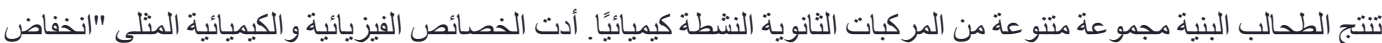

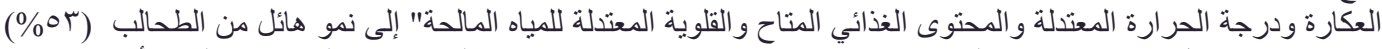

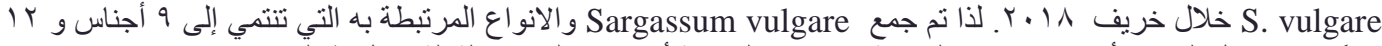

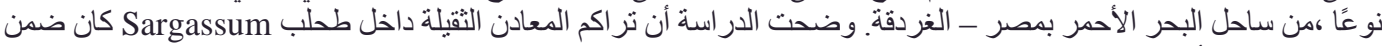

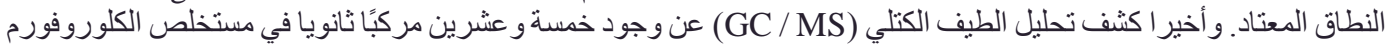
n-Hexadecanoic acid 28.23 \%, Heptacosane 14.04 \%, Oleic acid 9.10 \%, Octadecane, 3- 3 ethyl-5-(2-ethylbutyl) $4.8 \%$, Cholest-5-en-3-ol, 24-propylidene-, (3ß) 4.24\%, Ergosta-5,22-dien-3-

$\%$ Palmitoleic acid 3.56 , $\circ$, acetate, $(3 \beta, 22 \mathrm{E}) 4.21 \%$ 